\title{
Cultural Issues in the English Translation of Satish Alekar's Play Mahanirvan
}

PRASHANT MANNIKAR

\begin{abstract}
The translation is essentially a cultural activity. The instrument of translation is language and a language can't be dissociated from its culture. The inter-language translation poses various challenges to a translator especially when it is a literary translation. The chief among these is locating cultural equivalence in the target language. Another significant challenge is to select a proper approach to translation, that is, translation strategies. The present paper attempts a critical assessment of the English translation of Satish Alekar's trendsetting play Mahanirvan (1974) (The Dread Departure) in terms of the cultural issues in translation. For this purpose, the concepts in Translation Studies such as equivalence, literal and liberal translation, domestication, and foreignization have been critically used as these terms essentially focus on the cultural dimensions of the translation process. The focus of the article, however, is on the experiences of a reader of reading the text in its source language, that is, Marathi, and its target language, that is, English.
\end{abstract}

Keywords: Language, Culture, Translation, Equivalence, Domestication, Foreignization.

\section{Introduction}

The basic insights and the concepts in the Translation Studies are concerned with the nature, process, and function of translation. Since the subject matter of the present article is a literary translation, the concepts related to the literary translation have been taken into consideration to study the translation process in light of the relevant concepts. The literary translation differs from non-literary translations in 
many ways. A literary work of art contains a heavy load of cultural ethos. There is much implicit, more unsaid than explicitly said, in a literary work, and hence a reader has to read in between the lines. Moreover, a play having visual dimensions and performative idioms requires multiple perspectives for its appreciation. Since a literary work of art is essentially culture-specific and the languages are not equipped with compatible equivalences or substitutes, the translator has to face various challenges in transferring the text from a source language to the target language. He has to serve the two masters - the ST author and the TT recipient. This dichotomy has resulted in the debate over the nature, process, and function of the translation activity since Cicero of the Roman antiquity to the present and this date offers no conclusive solution to the issues in translation. Mary Snell-Hornby in this regard poignantly notes, "and what is not yet adequately recognized is how translation (studies) could help us communicate better - a deficit that sometimes has disastrous results" (2006: 166). The translation is essentially a cultural activity. Language can't be dissociated from its culture. The interlanguage translation poses various challenges to a translator. The chief challenge is finding cultural equivalence in target language for the expressions in the source language. The culture-specific expressions from the Marathi play Mahanirvan (1974) by Satish Alekar have been sorted out and compared with the equivalences in the English text. The English text The Dread Departure has been rendered by the noted Marathi and English author Gauri Deshpande. The researcher owes reverence to the translator for the painstaking effort of translating a literary text heavily loaded with a cultural ethos and by no means carries an authority to find faults with the text. However, a close reading of the original text in Marathi and its English version tossed up certain issues that prompted the researcher to carry out a comparative study 
of the two texts. The focus of the paper is on critical engagement with the central issues in inter-lingual translations related to the cultural aspects and the aesthetic taste of the texts both in the source language and in the target language. The paper is structured into three sections. The section I takes a historical survey of the emergence of Translation Studies as a discipline and explicates the concepts and strategies related to Translation Studies. Section II carries out a comparative study of the source language (Marathi) and target language (English) texts of Satish Alekar's play Mahanirvan. Section III puts the researcher's experiences as a reader of the SL and the TL texts.

\section{I}

Translation as an activity and a process has a long-standing history dating back to ancient times. The texts of the classic languages like Sanskrit, Greek, Roman/Latin, and Hebrew, just to name indicative few continued to be translated into the contemporary vernacular languages for the benefit of the masses. But the Translation Studies as a discipline consciously emerged during the latter half of the $20^{\text {th }}$ century. Mary SnellHornby (2006) in her scholarly work the Turns of Translation Studies: New Paradigms or Shifting viewpoints, has sketched the historical development of Translation Studies as an independent discipline. In this work, she points out that 'many basic insights and concepts in Translation Studies today go back to the German Romantic Age, which forms our historical starting point' (16). The process of translation hinges on the dichotomy between the Source Language author and the Target Language reader and the discourse of the Translation Studies revolves around addressing the issues emanating from this dichotomy. Werner Koller defines translation in the following words:

From a linguistic and text-theoretical perspective, translation can be understood as the result of a text- 
processing activity, by means of which a sourcelanguage text is transported into a target-language text (1995: 196).

The first and foremost of the issues in translation is that of 'fidelity' or 'loyalty'. Whether the translator should keep his/her fidelity to the SL author or should he serve the TT recipient? This basic insight and practical concern have initiated discussions on the procedures of Translation Studies. Munday (2008: 19) has succinctly put the contentions of Cicero that have cleft the translation discourse in two halves:

Very early in the history of translation, the dichotomy of obligations (ST-oriented) and desires (TT-oriented) of translators led to the discussion of literal vs. free translation that has split the world of translation theory ever since (quoted in Fassbender 2009).

This debate got a theoretical framework during the German Romantic Age. The German authors and scholars have made a remarkable contribution toward the framing of Translation Studies as an independent discipline. Friedrich Schleiermacher in 1813 was arguing about not having 'a theory of translation that is based on solid foundations, that is logically developed and completely worked out,' and emphasizing on 'and yet, just as there is a field of scholarship called Archaeology, there must also be a discipline of Translation Studies' (quoted in Mary Snell-Hornby: 2006). The basic contentions of Goethe and Schleiermacher provided the necessary framework for the rise of Translation Studies. Goethe's two maxims in translation opened up the discourse on the multilevel relationships in the players of translation - the author, the translator, and the reader. Lefevere puts the argument of Goethe in the following words:

There are two maxims in translation: one requires that the author of a foreign nation be brought across us in 
such a way that we can look on him as ours; the other requires that we should go across to what is foreign and adapt ourselves to its conditions, its use of language, its peculiarities (39).

The two maxims theory of Goethe serves as the base for Venuti's (1995) much discussed and debated distinction between 'domestication' and 'foreignization'. Yet another potent source for this distinction and the ensuing debate is Friedrich Schleiermacher's observation of the translation procedure. Like Goethe's two maxims, Schleiermacher came with the two roads open to the translator:

In my opinion, there are only two. Either the translator leaves the author in peace, as much as possible, and moves the reader towards him; or he leaves the reader in peace, as much as possible, and moves the author towards him (Lefevere 1977: 74).

The debate that continues without a conclusive statement is whether a translator should 'move a reader to the SL author' or 'move SL author to the (TL) reader'. Lawrence Venuti (1995) codified this fundamental dichotomy in the translation process as 'domestication' and 'Foreignisation' strategies. 'Foreignisation' promotes keeping the culture-specific expressions of the SL text intact in the TL text whereas 'domestication' emphasizes naturalizing or neutralizing the culture-specific expressions in the SL text by replacing them with the expressions of the TL cultural terminologies. 'Foreignisation' makes a translator maintain fidelity to the SL author and to take the reader abroad; 'domestication' offers him loyalty to the TL reader and to take the author to the reader. If Schleiermacher (1813) preferred 'moving the reader to the author', Jakob Grimm (1847) was advocating the need for 'moving author to the reader.' He maintained that 'no longer must the target language be bent to do justice to the source 
text, now the translator must accept that in the world of target language 'another breeze is blowing' ( quoted in Mary SnellHornby: 30). And before Grimm, A. W. Schlegel (1798) was categorically asserting that 'We look on foreign author as a stranger in our company, who has to dress and behave according to our customs, if he desires to please' (Lefevere: 50). The modern-day companion of Grimm and Schlegel, Eugene A. Nida advocated 'moving author to the reader'. In his article 'Principles of Correspondence', Nida (2000) observes:

Since no two languages are identical, either in the meanings given to corresponding symbols or in the ways in which such symbols are arranged in phrases and sentences, it stands to reason that there can be no absolute correspondence between languages. Hence, there can be no fully exact translations. The total impact of a translation may be reasonably close to the original, but there can be no identity in detail (126).

The argument of Eugene Nida empowers a translator in creating a new text close to the original but may not be identical in detail with it. For exacting translation, a translator has to work with the equivalences - the substitute signs for the source language. The substitution in the target language can never be similar to the source language but must have near equivalence as put aptly by Constance B. West, 'not with the same money but the same sum'. Nida puts forward two types of equivalences - formal or literal and dynamic or functional. The formal equivalence would retain the foreign elements in the SL text in the TL text, whereas the dynamic equivalence would substitute the culture-specific elements of the SL text with culture-specific expressions in the target language. He duly accords the role played by culture in the act of translation by admitting that differences between cultures may cause more severe complications for the translator than do differences in 
language structure. He described language as an integral part of a culture, words being symbols of cultural phenomena:

Translating consists in reproducing in the receptor language the closest natural equivalent of the source language, first in terms of meaning and secondly in terms of style (Nida \& Taber 1969: 12).

Languages are steeped into the cultures from which they emerge. The relationship between language and culture is reciprocal. Languages are never sufficiently similar to express the same realities 'reality cannot be assumed to exist independently of language. The distinguished critic Lotman rightly figures out that no language can exist unless it is steeped in the context of culture; and no culture can exist which does not have at its center, the structure of natural language. While Mona Baker points out that 'Languages are never sufficiently similar to express the same realities,' and that 'reality cannot be assumed to exist independently of language' (8). Elaborating on the inextricable relationship between language and culture, Susan Bassnett poignantly asserts, 'Language is the heart within the body of culture' (13). Bassnett further warns, "the translator must tackle the SL text in such a way that the TL version will correspond to the SL version. To attempt to impose the value system of the SL culture onto the TL culture is dangerous ground' (23). While keeping the translation strategies as the points of reference, the article attempts a comparative close reading of the Marathi and English texts of Satish Alekar's play Mahanirvan.

\section{II}

Satish Alekar belongs to the second generation of Marathi playwrights after the modernization of the Marathi theatre by the renowned playwright Vijay Tendulkar. The veteran playwright Vijay Tendulkar (1928-2008) played a phenomenal role in the shaping of modern Marathi theatre and also 
attributing it to Pan-Indian and Inter-national recognition. The Tendulkar phase proved to be an epoch-making event in the Marathi theatre. Tendulkar freed the Marathi theatre from the taboos and inhibitions both of the content and the form. He paved the path for the playwrights and theatre artists of the succeeding generations. Satish Alekar further experimented with the Marathi theatre in terms of subject matter and the stage performance. His play Mahanirvan first performed on 22 November 1974 took the Marathi audience and critics by storm with its subject matter and exquisite theatricalities. The subject matter of the play Mahanirvan is death and the rituals and rites that follow it. Death and the rituals related to it are sanctimonious on one hand and serious and of grave concern on the other. This entire affair in human life is tragic, woeful, and grave in nature. This could rarely be a matter of theatrical representation. Alekar chose and handled this taboo subject with genuine dramatic deftness. He disrobed the death rites and rituals from its serious and grave demeanor and brought the humour and laughter out of them through his characteristic slant view to look at the things around him.

The play Mahanirvan enacts the story of death and its aftermath of Bhaurao, an ordinary resident of Chwal in Pune city. The Chwal is a characteristic residence of Pune and Mumbai cities like today's apartments. But the Chwal differs from the modern-day apartments in terms of individual privacy. The residents of a Chwal usually belonged to the lower and lower middle classes. They shared many common amenities. They had a strong bond of relationships. The public and private affairs of the homes used to have a very thin line of demarcation. The Marathi literature of the 1950s onwards fruitfully used the Chwal and its residents as the subject matter. Especially P. L. Deshpande and V. P. Kale resourcefully exploited the locations and relationships in and around Chwals in Pune and Mumbai. Alekar uses this locale 
and its people as the subject of his play. Another significant aspect of the play is also related to the cultural dimensions of Pune city. There are a large number of temples in Pune city. Kirtan was and is a popular form of entertainment for the public. The Kirtan takes up a devotional subject for its narration. But it could be conveniently exploited for the explication of any subject or topic. The Kirtan could run into theatrical performances by the narrator and his aides that would include songs, allusions, metaphors, similes, pun, humour, hyperbole, anecdotes, and digressions, and so on. This form serves the purpose of dissemination of ideas as well as the correction of social follies through criticism of the ills of the society. A Kirtan may begin with a moral from the devotional writings and dive into the contemporary issues of the social, moral, religious, and political life of contemporary society. Alekar deftly used the Kirtan mode as the narrative technique for the play Mahanirvan. The twin aspects, the death rites, and rituals and the Kirtan mode of narration/action are essentially culture-specific. This poses a significant challenge to a translator translating into another language. If it is English then the translation task is quite tough as there is hardly any equivalence in the cultural practices either of the subject matter or the narrative treatment.

Alekar's play Mahanirvan is woven around the death of Bhaurao, a middle-aged ordinary resident of a Chwal. The play opens with the death of Bhaurao and proceeds with the postdeath rites and rituals. The other important characters in the play are Rama, Bhaurao's wife, and Nana, their only son. Apart from these, there are neighbors of Bhaurao referred to as 'Chwalkari' in the play. The play enacts the preparations for the funeral procession of Bhaurao, the cremation, and the rites after the cremation with many accidental digressions that take place in the course of the play. The mood of the play is to produce tongue-in-cheek humour out of a grave subject. It is a 
scathing criticism of some of the awkward rites practiced in the Hindu faith. The play may be treated as a comedy with black humour. It heavily uses the rich resources of the local and cultural expressions to add to the hilarious mood of the play. The Kirtan form of narration incorporates at a large scale the devotional songs and expressions. These aspects of the play put heavy challenges on a translator.

Satish Alekar denies any overt message intended in his plays. He conceives plays in strict relations with its medium, that is, its performance worthiness. Alekar shuns away from any didactic messaging through his plays. So any attempt of straining down some message from his plays, especially from Mahanirvan would be a gross mistake and an injustice to the play as well. Like a classical satirist, Alekar lay bares the dichotomies and pretentiousness in human transactions. His plays like Micky and the Memsahib (1973), Mahapoor (1975), Begum Barve (1979), and Atireki (1979) stand testimony to this aspect of Alekar's worldview. The play Mahanirvan epitomizes this worldview of Alekar. Hence, the translation of Mahanirvan in terms of the nature of the message and the purpose of the author stands no water. The third factor, the type of audience for whom the text might be translated, matters significantly. The play is translated into English obviously for the non-Marathi audience. Now, this readership could be either pan-Indian or it may accommodate the pan-Universal readership. Assuming that the reader or viewers of Mahanirvan get the least chance to read or watch its performance in the source language, that is, Marathi, the translation has been excellently and meticulously transacted. But for a reader from a Marathi speaking world, the English translation of the play poses certain issues in terms of the transaction of the cultural load of the text as it is communicated in the source language. Of course, this is not the problem of the translator. Rather, it is the problem of 
finding cultural equivalences that are rarely available for translation.

The first point of departure in the English translation of the play begins with the title of the play. The word Mahanirvan in the Indian context has deeply religious, social, and cultural overtones. Nirvana in general parlance evokes a place of perfect peace and happiness. It is synonymous with moksha salvation. In Hinduism and Buddhism, nirvana refers to the highest state of a being, a state of enlightenment consciously and rigorously achieved through practicing detachment and willful shunning away from all kinds of attachments either of the body or mind, matter or spirit. The suffix Maha refers to something great in status or stature. Mahanirvan evokes the willing departure of someone like a great yogi or karmayogi from the day to day commerce of life. Such a person transcends himself from the mundane busy world of desires and wishes and attains perfect bliss like the Buddha or the Mahanirvan. The word Mahanirvan in its general implication refers to the physical death of such an enlightened person. Alekar uses this heavily over toned expression for the death of an ordinary middle-aged, lower-middle-class man, Bhaurao. This leads to the parody of the word and the situation. The play assumes the stature of a mock-heroic episode. The tone of the play becomes extremely hilarious and comic. The play exploits many dramatic gimmicks like the telling the story of one's death by the dead himself, the use of extended soul, and allusions to the classic tragedies like Shakespeare's Hamlet. The play in the source language nowhere indicates anything grotesque, fearful, or ghastly in the proper sense of the words. There is nothing to be dreaded or to be afraid of about the situations or characters in the course of the play. The retaining of the title as Mahanirvan would have served the purpose of communicating the essential humour and irony in the play. The English translation of the play as 'The Dread Departure' 
misses the essential pun achieved by the large-scale expression Mahanirvan in the source language.

The play incorporates a minute detailing of the ordinary routine lives of the people in general. In every Indian household, there are specific salutations and addresses used by the husband and wife. In Marathi speaking world, as it is in other Indian language communities, addressing husband and wife by their names is usually avoided. Instead, language and culture-specific expressions are used, especially in the public context. In Marathi, a wife usually addresses her husband as 'Aho' [a-ho]. This address is honorific as well as shows respect and love for the husband. Likewise, the husband addresses his wife as 'Aaga' [a-ga] in private and refers to her as 'Mandali' [man-da-li] in public talks. In the opening scene of the play, Rama, Bhaurao's wife addresses him with a characteristic 'Aho' as he doesn't come out of bed even at the noon. The English expression 'Come on' can't carry the tenderness and other cultural overtones of the expression 'Aho'. The Indian married life has many intricate terminologies that are deeply associated with the social, religious, and cultural behavioral patterns of the society. A married woman carries many cultural and social artifacts with her that distinguish between a married, unmarried, and widowed woman. Some of the identity markers of a married woman are ornaments like 'Mangalsutra' and a 'Kumkum' mark or 'Bindi' on the forehead. The husband is reckoned with as the lord of the Kumkum mark, Kunkawacha Dhani [kunkawa: cha: dhani]. As per the marriage rituals, the husband and wife take seven circles around the holy fire known as 'Saptapadi' [sapta-padi]. When Bhaurao expresses his concerns over his untimely death and thus leaving the conjugal life with Rama halfway, he utters these culturespecific expressions. The translated text skips these expressions. In the Indian context, a husband is treated as a god, a common term being 'Patidev'. Bhaurao assures Rama 
that he is her 'Patidev'. The translation of this expression goes like 'Your one and only husband'. The 'one and only' falls short in evoking the pun in the expression 'Patidev'.

The notion of 'Sutak' [sutak] is a characteristic feature of the Indian way of social and cultural life. The 'sutak' refers to observing untouchability on certain occasions especially such as death. In the event of the death of a person, the blood relatives of the deceased observe 'sutak'. Society refrains from having any form of physical contact with them. It is mutually carried out in social practice. It is not like the practice of untouchability in the social order observed once upon a time in Indian social life. Bhaurao refers to this 'sutak' after his death in warning his wife against her touching of his dead body. The translation 'if you touch now, I'll become untouchable too; in mourning for myself' can't fetch the cultural associations of the specific untouchability. Another culture-specific example in the play is that of a song sung addressing Rama, now a widowed wife of Bhaurao. Bhaurao assumes that in his absence the male folk of the society may take the undue advantages of his beautiful and comparatively 'young' wife. He imagines that Rama is eating an apple, clad in red 'saree', and kumkum on the forehead and the neighbours encircle her and sing a song. The song in the source language is a folk devotional song in praise of the goddess of 'Shakti' known as 'Ambabai'. 'Ude ga Ambe Ude' is a traditional devotional song sung in praise of the goddess. Alekar rewords this song as 'Ude ga Rame Ude'. The English translation 'Wake up, Rama, wake up' could not carry the intended pun in the song of the source language. Another expression from the song 'We're upright folk and neighbourly, who will be eating their bread with honey' in the English text misses the social and cultural idiom 'we're pious morally keen people, and eat chapatti (Poli) with ghee (purified butter) (Tup Marathi word for ghee or purified butter). The expression eating 'poli with tup' 
(chapatti with ghee) refers to the elite class of people on the social ladder. Eating 'bread with honey' is still not a social, cultural pan-Indian practice.

Some of the social and cultural connotations add challenges to the translation in English. For instance, the dry vomiting by women, particularly young and married, in the Indian context is indicative of the early signs of pregnancy. The pregnancy of the unwed woman is still a taboo and a social and cultural offense in the Indian social set up. Bhaurao mentions that the long preserved Ganga-water poured on his lips as a part of the death ritual made him sick and almost vomit it out. He makes a hypothetical instance that instead of him, had there been an unwed young woman who died and started making dry vomiting like him people would have turned the natural death of the woman into a suspicious suicide owing to social stigma. The translation of this hypothetically humorous narration goes like 'A poor young unmarried girl who'd died in her sleep will be branded as suicide if you could hear her dry rattle, trying to throw up the basil-leaf and Ganga water!' The translated text misses the socio-cultural invocations of the expression of the dry vomiting associated with the social stigma of the pregnancy of the unwed woman. Bhaurao is rumored to have an extramarital relationship with one of the neighbours named as Bandu Joshi's mother. In the absence of Nana, Bhaurao's son, it is assumed that Bandu Joshi offers to light the pyre of Bhaurao. The women folk discuss that Bandu Joshi's face is similar to that of Bhaurao. This is how the expression goes in the source text. Its English version runs as 'Nana and Bandu are as likes as peas in a pod'. The pleasure sourced out of the hints dropped by the expression that Bandu's face resembles Bhaurao is punctured by the direct reference to Bandu and Nana being fathered by Bhaurao. 
Yet another classic example of the untranslatability of the cultural ethos is the traditional game of singing songs by the groups during which the participants have to take up the last alphabet of the song and begin a song with that alphabet. It continues in this way till one group or its member declares that they or he cannot find a song beginning with the last alphabet of the preceding song. This popular game is known as 'Bhendya' in Marathi. The neighbours of Bhaurao awaiting the arrival of Nana for taking the funeral procession to the crematorium decide to play this game to pass off the boredom of waiting. The entire episode phrased as 'Last letter starts the rhyme' runs as follows:

Left Group: Come all ye faithful,

Joyful and triumphant,

Come, all come to Bethlehem.

$\mathrm{M}$ ! M!

Right Group: Michael, row the boat ashore.

Hallelujah!

Michael, row the boat ashore, Hallelujah!

Sister, help us with the oars, Hallelujah!

\section{A! A!}

Left Group: Hark, the herald angels sing

A new king born today.

Mary's boy child Jesus Christ

Was born on $X^{\prime}$ mas Day

$\mathrm{Y}$ ! Y!

Right Group: You are my shepherd, Lord!

(And the other group joins in.)

You are my savior,

You are my shepherd, Lord,

You'll gather me in.

Now such a game is out of context at the grave occasion of death. The obvious intention of using this dramatic prop is to 
produce laughter. The neighbours from the Chwal who have come for the preparations of Bhaurao's funeral procession divide themselves into two groups and start playing this game of songs. The songs they sing are the devotional rhymes and prayers attributed to the Hindu deities like Lord Datta, Lord Krishna, Lord Rama, and Lord Vithala or Panduranga. The English text skips these references and attributions to the Hindu deities and instead does away with the Christian rhymes, rather hymns.

\section{III}

The substitution of the religious and cultural rhymes or rather hymns with the hymns of another cultural or religious faith could be well justified supposing the international readers or audience as the target audience. It could also be justified by applying the argument by Constance $\mathrm{B}$. West that a translator may pay the debts 'not with same money but the same sum'. However, this attempt and other instances referred to in the article exemplify the use of Domestication strategy in translation. The sense and the candor of the cultural ethos have been happily sacrificed for the appropriation of the target language, target text, and receivers. In the event of the performance of this text in the English speaking world, such kind of strategy would be a welcome initiative. But this could have been avoided keeping in view the Indian receivers of the non-Marathi speakers. Moreover, there are many instances where the source-language culture-specific instances have been kept intact in the target language text. The mixture of Domestication and Foreignization strategies have resulted in the implications recorded in the visionary wise words of Schleiermacher:

these two paths ['moving the reader to the author' and 'moving the author to the reader'] are so very different from one another that one or the other must certainly be followed 
as strictly as possible, any attempt to combine them being certain to produce a highly unreliable result and to carry with it the danger that writer and reader might miss each other completely" (Lefevere 1977: 74).

The application of the Foreignization translation strategy would have kept the essential cultural ethos of the text intact even in the target language. The retaining of the culturespecific aspects in the text even at the expense of the candor and decorum of the target language conventions would have rendered the better reading experience of the translated text.

\section{References}

Alekar, Satish. 2009. Collected Plays of Satish Alekar. New Delhi: Oxford University Press.

BAKER, MONA.1992. In Other Words: A Coursebook on Translation. London \& New York: Routledge.

BassnetT, Susan. 1980. Translation Studies. USA \& Canada: Routledge.

FASSBENDER, RENE. 2009. Translation Theory: Domestication and Foreignization. Munrich: GRIN Verlag. https://www.grin.com/document/31036.

Hornby- Snell, MARY. 2006. The Turns of Translation Studies: New Paradigms or Shifting viewpoints? Amsterdam/Philadelphia: John Benjamins.

KOLlER, WERnER. 1995. The Concept of Equivalence and the Object of Translation Studies. Target 7 (2). 191-222. https://benjamins.com/online/target/articles/target.7.2.02kol LEFEVERE, ANDRE. 1977. Translating Literature. The German Tradition from Luther to Rosenzweig. Assen/Amesterdam: Van Gorcum.

NidA, Eugene A. and Charles TABer. 1969. The Theory and Practice of Translation. Leiden: Brill. 
Prashant Mannikar

NidA, EugEne A. 2000. Principles of Correspondence. In Lawrence Venuti (ed.), The Translation Studies Reader, 126-140. London: Routledge.

Venuti, LAWRENCE. 1995. The Translator's Invisibility: A History of Translation. London \& New York: Routledge.

$$
* * *
$$

\section{Cite this Work:}

MANNIKAR, PRASHANT. 2020. Cultural Issues in the English Translation of Satish Alekar's Play Mahanirvan. Translation Today, Vol. 14(2). 63-80. DOI:10.46623/tt/2020.14.2.ar4 